\title{
Understanding Consumer's Acceptance of Technology-Based Innovations in Retailing
}

\author{
Eleonora Pantano' \& Loredana Di Pietro²
}

\begin{abstract}
The availability of a huge number of studies about the Technology Acceptance Model (TAM) for predicting consumer's acceptance and usage of innovations in points of sale motivates writing of the present. Review, with emphasis on the new variables integrated in the traditional model. This is concerned with a synthesis of the current progresses in the field, thus offering a unified view of consumers' behaviour towards new technical solutions. Such synthesis is achieved from an extensive literature analysis, including computer science, innovation, human-computer interaction, and technology management perspectives. For each case, both opportunities and issues are outlined in order to advance the current knowledge and highlight what practitioners and scholars should take into account for developing new and efficient corporate strategies.
\end{abstract}

Keywords: technology acceptance model (tam); technology adoption; innovation; consumer's behaviour; retailing.

\footnotetext{
'Department of Business Science, University of Calabria, via P. Bucci, cubo 3B, 87036 Arcavacata di Rende-CS, Italy, 00390984492235 , eleonora.pantano@unical.it

2Department of Management, University of Molise, via De Sanctis, 86100 Campobasso, Italy, 0039087440446 I,

loredana.dipietro@unimol.it
} 


\section{Introduction}

The last decade has seen an increasing interest towards the application of Information and Communication Technologies (ICT) in several fields. While early contributions to retail domain focused mostly on developing of e-commerce and ebanking services, more recent works have been investigating the best practices to design advanced technologies, in order to improve traditional physical points of sale as well (Pantano and Corvello 2010; Willow 2010). From a consumer's point of view, the benefits provided by such technologies are several. First, they are able to improve the offered services. Second, they can support consumers' decision-making process. Third, they can enhance the shopping experience (Simmons and Istook 2003; Vieira 2010). Thus, it should not be a surprise that, recently, many interactive tools have been introduced in traditional stores, such as interactive kiosks and floors, in-store displays, smart-mirror, RFID systems, virtual salesperson, shopping assistant systems based on shopping trolleys and handled devices (Chiu et al. 20 I0a,b; Dennis et al. 2010; Kim and Niehm 2009; Vijayaraman et al. 2008), and anthropormiphized shopping assistants, and immersive environments (Jin 2009; Pantano and Laria 2012; Pantano and Servidio 2012). These in fact can make traditional stores more attractive and aesthetically appealing, thus influencing consumer's shopping behaviour.

The main feature characterizing these technologies is their capability to provide detailed and constantly updated information on products and services available in the stores (i.e. price, promotions, special discounts, etc.), which users can access through entertaining and user-friendly interfaces (Breugelmans and Campo 201 I; Willow 2010). As a consequence, stores may become more appealing and more convenient in terms of time, place, and purchasing modalities, hedonic value (Hsiao 2009; Yoon and Kim 2007); they may be able to enhance the shopping experience with benefits for the consumers shopping mode choice. Hence, the advanced technologies in the one hand provide customized information and services which consumer can access according to his/her own needs (Puccinelli et al. 2009; Reinders et al. 2008); in the other they provide managers information on consumers' behaviour, preferences and market trends (Chiu et al. 20 10a,b; Ochi et al. 2010). This rising interest in designing advanced tools also for retailing follows the increasing awareness in the consumers' increasing power and possibility to choice among alternatives, as well as on the opportunities for co-creating innovative products and services (Berry et al. 2010;Alexander et al. 2009; Eastlick et al. 2012; Weng et al. 20I2).

Previous studies on users' acceptance of new technologies mainly focused on the exploitation of Technology Acceptance Model (TAM) (Davis 1989), which can be successful- ly applied also at retailing and consumers' usage of a new system in the points of sale (Pantano and Servidio, 20I2). Hence, there is a huge amount of studies on the extended TAM, thus the need of a review able to synthesis the current progresses in this direction emerges for proposing a unified view of consumers' behaviour towards the new technical solutions in the points of sale. The aim of this paper is to provide a more comprehensive view of current researches in marketing and management studies, by reviewing the extant literature on TAM for advanced technology-based innovations for retailing including computer science, innovation management, human-computer interaction, and technology perspectives. We pursue this objective by reviewing studies that provide summaries of the variables and key findings of papers that directly address TAM. To achieve this task, we outline opportunities to enrich the knowledge of the phenomenon along with issues that practitioners and scholars should take into account for the development of new and efficient corporate strategies.

The first part of the paper is devoted to the definition of emerging lines of inquiry and discussions of the theoretical contributions to the overall understanding of the phenomenon; whereas the second one focuses on the avenues for future perspectives, research methods and directions, suggestions on possible overviews for improving understanding of theoretical and practical issues emerged from the analysis.

\section{Conceptual framework}

In the last decades an important line of inquiry focused on users' acceptance of new technologies has emerged, by understanding the main variables able to predict the actual usage of a system, in order to properly tailor new services and products to the market based on Technology Acceptance Model (Davis, 1989). In fact, literature proposes a wide range of successful applications at several sectors, such as e-learning (Liu et al. 2009; Liu et al. 2010), e-commerce (Pavlou 2003; Yoon 2009; Wu and Wang 2005), hospitality and tourism (Casalò et al. 2010, Chang and Caneday 201 I; Kim et al. 2008; Kim et al. 2009), learning (Wan Ismail 20I2) and so on. In particular,TAM is based on the Theory of Reasoned Action (TRA) (Fishbein and Ajzen 1975) with the purpose to describe computer usage behaviour. Initially, it has been largely involved to predict Internet adoption, by mainly focusing on the constructs of perceived ease of use and perceived usefulness, attitude and behavioural intention (Figure I).While perceived usefulness is related to the utility value emerging from the system usage and it can be defined as the degree to which a person believes that using a certain technology will enhance his/her performance (Kim et al. 2008; Lee et al. 2005), perceived ease of use represents the degree to which a person believes that using the particular technology will require no effort (Kim et al. 2008). Both these 


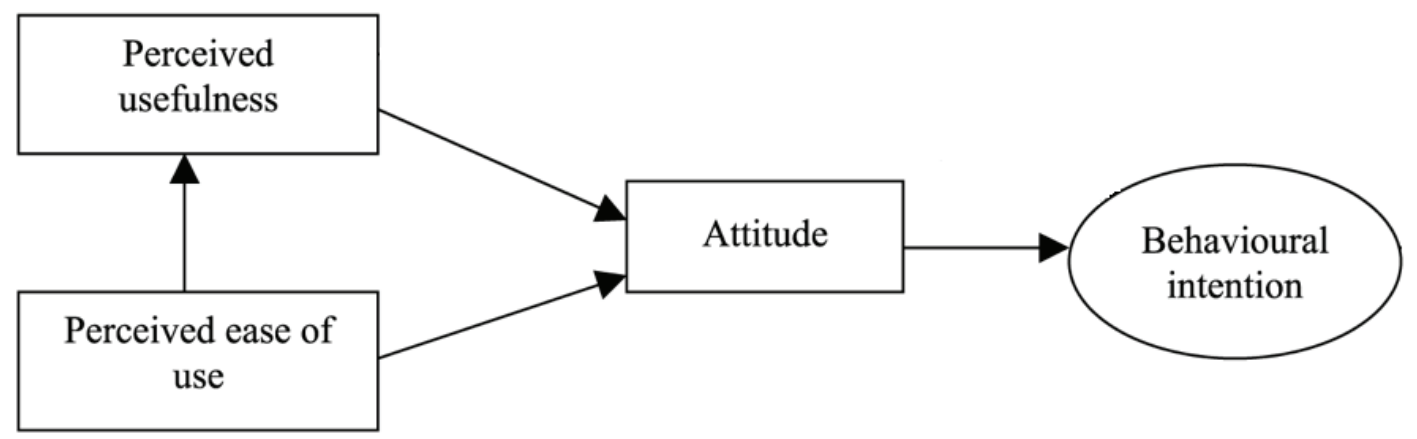

Figure I.Technology Acceptance Model (TAM) developed by Davis (1989)

variables affect the attitude and the subsequent behavioural intention (Kim et al. 2009). Attitude represents user's assessment toward the technology, whereas the behavioural intention represents the degree to which the user is willing to perform certain behaviour.

TAM has been further extended with several sets of acceptance determinants for developing subsequent prominent models capable of better predicting user's behaviour across different fields of application (Venkatesh et al. 2003; Venkatesh et al. 2012).

Authors identified the importance of Technology Acceptance Model also for retail sector, due to the increasing number of possible technical solutions (Pantano and Servidio 2012). This sector includes both the applications at the physical point of sales (i.e. new automatic cash desk) and virtual ones (i.e. virtual sellers). A common attempt to investigate consumers' acceptance of new technologies in retailing focuses on their attitude towards ecommerce and eservices (Han and Jin 2009; Ha and Stoel 2009; Hernandez et al. 20 I0; Shen and Chiou 2010; Udo et al. 2010; Wu 2010) such as electronic payment modalities (Kim et al. 20I0; Schierz et al. 2010), online recommendations (Baier and Stuber 2010; Kowatsch and Maass 2010), internet banking (Al-Somali et al. 2009; Alsajjan and Dennis 2010; Lee 2009; Muller-Seitz et al. 2009; Vrechopoulos and Atherinos 2009; Yoon 2010, Yousafzai et al. 2010), as well as self-service systems (Chen et al. 2009a; Dimitriadis and Kyzeris 20 I I; Lee et al. 20I I; Liu et al. 2012; Oghazi et al. 20I I; Weng et al. 2012; Eastlick et al. 2012; Pantano and Viassone 20I2); whereas other studies in the broad domain of physical stores focus on the introduction of technologies such as RFID, smart mirror, smart shopping trolleys and so on. Event if these studies follow the common approach supported by TAM, they show an absence of a dominant perspective in the field of retailing by adding a wide range of variables (i.e. social influences, informative functions, facilitating conditions, system quality, etc.).

\section{Literature review method}

As indicated by Greenhalgh and Peacock (2005) and Ravasi and Stigliani (in press), the selection of research results merged a protocol-driven methodology (the search strategy is defined at the beginning of the study) with a snowballing technique (the search strategy emerges as the study unfolds). Following the authors, we first used databases including the ScienceDirect, IEEE Explore,ACM Digital Library and Scopus search engines in order to provide a broad review of the current literature on Technology Acceptance Model. In this way, the expected outputs represent the most important academic contributions related to consumer's acceptance of new technologies in physical and virtual points of sale.

Due to the large amount of technologies introduced in past decades, we decided to focus just on the most recent technologies. To achieve this task, we limited the research to works published from 2009 to present.

Since several terms may potentially refer to TAM, we used a number of words or phrases in titles or as keywords, we retrieved all papers published in the "Business and Management", "Marketing" and "Computer Science" categories of the databases with titles, abstracts or keywords containing the expressions "technology acceptance model" and "consumer acceptance". This criterion generated an initial set of more 450 contributions. In order to accurately screen the initial set of works, we read all the abstracts and searched for studies on TAM in retailing, and for conceptual articles that advanced understanding of TAM, all written in English. In addition, in order to identify papers potentially missed in such searches, we conducted targeted searches of journals with heavier focus on these topics in the Scopus database, as well as the Elsevier and Emerald databases. We also conducted manual searches of numerous reference lists to identify additional relevant papers and searched an electronic library catalogue for relevant contributions. This further round yielded II additional articles. Subsequently, we filtered through the bibliographies of the articles selected

ISSN: 07 I8-2724. (http://www.jotmi.org) 
so far, searching for additional TAM articles not captured by previous rounds of review. This branching and cross-referencing method allowed us to add 18 additional articles.

The focus of the search was exclusively within peer-reviewed journal articles from a range of international sources. We excluded short essays reporting personal reflections and articles that, although containing an overview of the topic/abstract, referred to TAM only marginally and really focused on other issues, such as new technology ventures and the management of other information and communication systems. This round of review led us to select 130 articles published between 2009 and 2012 (August): 35 of 2009, 38 of 2010,
42 of 201 I, I 5 of 2012 (August). These numbers reflect the emergent nature of the topic.

At this stage, we carefully read the content of each article and began to map the selected literature in order to identify core themes, reflecting various streams of research in investigating different aspects of TAM. Following past reviews in management and marketing studies, we exploited two combined criteria for the classification of outputs: (i) the conceptualization of the object of analysis, and (ii) the specific research topic and focus of investigation. Hence, we first categorized articles on the basis of their explicit or implicit conceptualization of TAM (i.e. TAM for the use of

\begin{tabular}{|c|c|c|}
\hline Frequency & Variable & Definition \\
\hline 11 & Perceived cost & $\begin{array}{l}\text { Consumers' belief of the cost concerning the new technology usage. If it is } \\
\text { high, they will be reluctant to the effective usage, thus high cost of value-add- } \\
\text { ed service provided by the technology may negative affective their intention to } \\
\text { adopt the technology. }\end{array}$ \\
\hline 11 & Perceived security & $\begin{array}{l}\text { The degree to which a consumer believes that using a certain technology will } \\
\text { be secure. It concerns the privacy and perceived risk in transaction, especially } \\
\text { when customer has not experience with the electronic service }\end{array}$ \\
\hline 12 & Subjective norms & $\begin{array}{l}\text { These norms represent the expectations of other people regarding to perform } \\
\text { a particular behaviour, thus they represent how a person is influenced by the } \\
\text { perception of his/her behaviour by reference people such as family and fiends. }\end{array}$ \\
\hline 12 & Satisfaction & $\begin{array}{l}\text { A feeling emerging from the consumers' experience with a product. This con- } \\
\text { struct measures the assessments of the experience including overall pleasure } \\
\text { related with the service received }\end{array}$ \\
\hline 12 & Self efficacy & $\begin{array}{l}\text { Consumer's judgement of his/her capabilities to perform a certain behaviour. } \\
\text { It is strictly linked to the behavioural control (or controllability) }\end{array}$ \\
\hline 13 & Behavioural control & $\begin{array}{l}\text { Personal resources for performing a certain behaviour. Since consumers who } \\
\text { need high control are more willing to use the technology which involves them } \\
\text { in the co-production of the service, this variable motivates customers to use } \\
\text { the technology }\end{array}$ \\
\hline 16 & Social influence & Influences of other people in performing such behaviours. \\
\hline 20 & Perceived risk & It concerns the uncertainty involved in purchasing processes. \\
\hline 30 & Trust & $\begin{array}{l}\text { A psychological state involving the intention to accept vulnerability of a posi- } \\
\text { tive expectations o another behaviour. }\end{array}$ \\
\hline 31 & Enjoyment & $\begin{array}{l}\text { The degree to which consumer perceives a certain technology as pleasant. } \\
\text { This represents an emotional state or an intrinsic motivation capable of stimu- } \\
\text { lating consumers in continuing such behaviours. In fact, consumer who ex- } \\
\text { hibits pleasure while shopping are more interested in the entertaining shops in } \\
\text { terms of longer and more frequent visits. }\end{array}$ \\
\hline
\end{tabular}

Table I.The most investigated variable within past literature

ISSN: 07 I8-2724. (http://www.jotmi.org)

Journal of Technology Management \& Innovation (c) Universidad Alberto Hurtado, Facultad de Economía y Negocios. 
mobile recommendations system). Subsequently, to achieve a more fine-grained picture of the structure of the topic, we categorized articles on the basis of their research topic: the focus of their investigation, the questions driving their research and the variables included in the model.

The research has been supported by the MaxQda software, in order to identify the most used variables in the studies mainly based on TAM in retail context. The software allowed coding and classifying each variable introduced in addition to the standard constructs of perceived ease of use, perceived usefulness, attitude, behavioural intention in order to propose an extended model. As a consequence, we were able to identify the new variables and their weight in the analysed literature. From the research 149 new variables emerge. Basing on our results, we ignored the variables introduced in less than II works. Accordingly, the most important ones emerged as following (see Table I): perceived cost (frequency value II), perceived security (frequency value II), satisfaction (frequency value 12), self efficacy (frequency value 12), behavioural control (frequency value 13), subjective norms (frequency value 12), social influence (frequency value 16), perceived risk (frequency value 20), trust (frequency value 30 ) and enjoyment (frequency value $3 \mathrm{I}$ ).
As expected, the analysis produced a synthesis of the review outcome, which would advance our knowledge in the phenomenon and highlight the emerging insights and issues for further researches.

Table 2 summarizes the main variables that represent the core streams of research on Technology Acceptance Model for retailing with the related publications. We classified these streams in other to identify a research agenda and possible methods to pursue this one.

\section{Extended Technology Acceptance Model: New variables}

We grouped the 10 variables achieved into four main areas of research, to focus on their convergence in explaining the consumer's acceptance of a new technology, namely perceived technology safety and cost, personal skills, social pressure and hedonic value. In particular, these variables have been grouped according the similarity and the reciprocal influences. In the remainder of the paper, we outline their conceptual foundations and summarize the main findings.

\begin{tabular}{|c|c|c|}
\hline Variables & Journals & Authors \\
\hline $\begin{array}{l}\text { Subjec- } \\
\text { tive norm }\end{array}$ & $\begin{array}{l}\text { Electronic Commerce Research and Applications (2); IEEE } \\
\text { International Technology Management Conference; Interna- } \\
\text { tional Journal of Marketing Studies; Journal of Applied Social } \\
\text { Psychology; Journal of Business Research; Journal of Com- } \\
\text { puter Information Systems; Journal of Retailing and Consum- } \\
\text { er Services; Technology in Society; The Electronic Library; } \\
\text { Tourism Management (2) }\end{array}$ & $\begin{array}{l}\text { Alsajjan and Dennis, 2010; Casalò et } \\
\text { al., 2010; Chang and Chang, 2009; } \\
\text { Kim et al., 2011; Lee, 2009; Lee and } \\
\text { Chen, 2010; Nasri and Charfeddine, } \\
\text { 2012; Pookulangara and Koesler, } \\
\text { 2011; Rouibah et al., 2011; Schierz et } \\
\text { al., 2010; Shuang, 2011; Yousafzai et } \\
\text { al,. 2010 }\end{array}$ \\
\hline $\begin{array}{l}\text { Self ef- } \\
\text { ficacy }\end{array}$ & $\begin{array}{l}\text { The Service Industries Journal; Behaviour \& Information } \\
\text { Technology; Computers in Human Behaviour (2); Decision } \\
\text { Support Systems; Electronic Commerce Research and Ap- } \\
\text { plications; European Journal of Marketing; Interacting with } \\
\text { Computers; International Conference on Mobile Business; In- } \\
\text { ternational Journal of Marketing Studies; Journal of Business } \\
\text { Research; Journal of Computer Information Systems; Journal } \\
\text { of the Operational Research Society; Journal of Retailing and } \\
\text { Consumer Services; Technovation }\end{array}$ & $\begin{array}{l}\text { Liu et al., 2012; Al-Somali et al., 2009; } \\
\text { Hernandez et al., 2009a; Hernandez et } \\
\text { al., 2009b; Hernandez et al., 2010; Irani } \\
\text { et al., 2009; Kim et al., 2011; Lee and } \\
\text { Chen, 2010; Luo et al., 2010; Nasri and } \\
\text { Charfeddine, 2012; Ooi et al., 2011; } \\
\text { Pookulangara and Koesler, 2011; Shin, } \\
\text { 2009a; Shin 2009b; Sun et al., 2009 }\end{array}$ \\
\hline $\begin{array}{l}\text { Satisfac- } \\
\text { tion }\end{array}$ & $\begin{array}{l}\text { Industrial Management and Data Systems; Advances in } \\
\text { EECM; Computers in Human Behaviour; European Journal } \\
\text { of Marketing; Information \& Management; Interacting with } \\
\text { Computers; International Journal of Information Management } \\
\text { (2); Journal of Business Research (2); Journal of Consumer } \\
\text { Marketing; Telecommunications Policy }\end{array}$ & $\begin{array}{l}\text { Chen et al., 2009; Hernandez et al., } \\
\text { 2009a; Hernandez et al., 2009b; Her- } \\
\text { nandez et al., 2010; Kang and Lee, } \\
\text { 2010; Li et al., 2012; Palvia, 2009; } \\
\text { Taylor and Strutton, 2010; Thomas and } \\
\text { Veloutsou, 2011; Tseng and Lo, 2011; } \\
\text { Udo et al., 2010; Yoon, 2010; Yu Jang } \\
\text { and Noh, 2011 }\end{array}$ \\
\hline
\end{tabular}

ISSN: 07 I8-2724. (http://www.jotmi.org)

Journal of Technology Management \& Innovation (C) Universidad Alberto Hurtado, Facultad de Economía y Negocios. 


\begin{tabular}{|c|c|c|}
\hline $\begin{array}{l}\text { Social } \\
\text { influence }\end{array}$ & $\begin{array}{l}\text { International Journal of Retail \& Distribution Management; } \\
\text { Behaviour \& Information Technology; Computers in Human } \\
\text { Behaviour (2); Expert Systems with Applications; IEEE In- } \\
\text { ternational Technology Management Conference (2); Indus- } \\
\text { trial Management \& Data Systems; International Conference } \\
\text { on Mobile Business; International Conference on MultiMedia } \\
\text { and Information Technology; International Journal of Digital } \\
\text { Content Technology and its Applications; Journal of the Op- } \\
\text { erational Research Society (2); Technovation; Tourism Man- } \\
\text { agement }\end{array}$ & $\begin{array}{l}\text { Chiu et al., 2009; Al-Somali et al., } \\
\text { 2009; Chen et al., 2011; Chong et al., } \\
\text { 2012; Du et al., 2010; Hongxia et al., } \\
\text { 2011; Hu et al., 2012; Irani et al., 2009; } \\
\text { Jayasingh and Eze, 2009; Pai and Tu } \\
\text { 2011; San Martín and Herrero, 2012; } \\
\text { Shin, 2009a; Shin, 2009b; Shin and } \\
\text { Chiou, 2010; Wei et al., 2009; Wu, } \\
2010\end{array}$ \\
\hline $\begin{array}{l}\text { Perceived } \\
\text { cost }\end{array}$ & $\begin{array}{l}\text { Behaviour \& Information Technology; Computers in Human } \\
\text { Behaviour (2); Electronic Commerce Research and Applica- } \\
\text { tions (2); IEEE International Technology Management Con- } \\
\text { ference (2); Industrial Management \& Data Systems; Interna- } \\
\text { tional Conference on Mobile Business; Journal of Computers; } \\
\text { Technological and Economic Development of Economy }\end{array}$ & $\begin{array}{l}\text { Chong et al., 2012; Hongxia et al., } \\
\text { 2011; Kim et al., 2011; Ooi et al., 2011; } \\
\text { Sawng et al., 2011; Shin, 2009a; Shin, } \\
\text { 2009b; Sun et al, 2009; Sun et al., } \\
\text { 2010; Ting Pan and Cao, 2011; Wei et } \\
\text { al., } 2009\end{array}$ \\
\hline $\begin{array}{l}\text { Behav- } \\
\text { ioural } \\
\text { control }\end{array}$ & $\begin{array}{l}\text { Electronic Commerce Research and Applications (2); IEEE } \\
\text { International Technology Management Conference; Interna- } \\
\text { tional Conference on Mobile Business; International Journal } \\
\text { of Marketing Studies; Journal of Applied Social Psychology; } \\
\text { Journal of Computer-Mediated Communication; Journal of } \\
\text { Promotion Management; Tourism Management (2); Transpor- } \\
\text { tation Research Part C }\end{array}$ & $\begin{array}{l}\text { Casalò et al., 2010; Jayasingh and Eze, } \\
\text { 2009; Jiang et al., 2009; Jou et al., } \\
\text { 2011; Kim et al., 2011; Lee, 2009; Lee } \\
\text { and Chang, 2011; Nasri and Charfed- } \\
\text { dine, 2012; Shuang, 2011; Sun et al., } \\
\text { 2009; Sun et al., 2010; Yousafzai et al., } \\
\text { 2010 }\end{array}$ \\
\hline $\begin{array}{l}\text { Perceived } \\
\text { security }\end{array}$ & $\begin{array}{l}\text { Electronic Commerce Research and Applications; Interna- } \\
\text { tional Conference on Management of e-Commerce and e- } \\
\text { Government; Computers in Human Behaviour; Journal of Ap- } \\
\text { plied Social Psychology; Electronic Commerce Research and } \\
\text { Applications; International Conference on MultiMedia and } \\
\text { Information Technology; Journal of Retailing and Consumer } \\
\text { Services; Behaviour \& Information Technology; International } \\
\text { Journal of Marketing Studies; Computers in Human Behav- } \\
\text { iour; Journal of Hospitality Marketing \& Management; Infor- } \\
\text { mation \& Management }\end{array}$ & $\begin{array}{l}\text { Du et al., 2010; Han and Jin, 2009; Mo- } \\
\text { rosan, 2011; Muller-Seitz et al., 2009; } \\
\text { Nasri and Charfeddine, 2012; San } \\
\text { Martin Gutiérrez et al., 2010; Schierz } \\
\text { et al., 2010; Schilke and Wirtz, 2012; } \\
\text { Shin, 2009a; Shin, 2009b; Yoon, 2010; } \\
\text { Yousafzai et al., } 2010\end{array}$ \\
\hline $\begin{array}{l}\text { Perceived } \\
\text { risk }\end{array}$ & $\begin{array}{l}\text { African Journal of Business Management; Computers in Hu- } \\
\text { man Behaviour (3); Decision Support Systems; Electronic } \\
\text { Commerce Research and Applications; IEEE Transactions } \\
\text { on Engineering Management; IEE International Symposium } \\
\text { on Information Engineering and Electronic Commerce; IEEE } \\
\text { International Technology Management Conference; Innova- } \\
\text { tion Management and Industrial Engineering; International } \\
\text { Conference on Information Management; International Con- } \\
\text { ference on Management of e-Commerce and e-Government; } \\
\text { International Journal of Digital Content Technology and its } \\
\text { Applications; International Journal of Information Manage- } \\
\text { ment; Journal of Business Research; Journal of Promotion } \\
\text { Management; Journal of Computers; Journal of Research in } \\
\text { Interactive Marketing; Journal of Retailing and Consumer } \\
\text { Services; Technological and Economic Development of Econ- } \\
\text { omy; Transportation Research Part C }\end{array}$ & $\begin{array}{l}\text { Benamati et al., 2010; Faqih, 2012; } \\
\text { Han and Han, 2009; Han and Jin, 2009; } \\
\text { Hongxia et al., 2011; Hu et al., 2009; } \\
\text { Hu et al., 2012; Jiang, 2009; Jou et } \\
\text { al., 2011; Lee, 2009; Lorenzo-Romero } \\
\text { et al., 2011; Liu and Forsythe, 2011; } \\
\text { Luo et al. 2010; San Martin Gutiérrez } \\
\text { et al., 2010; Sawng et al., 2011; Shen } \\
\text { and Chiou, 2010; Taylor and Strutton, } \\
\text { 2010; Ting Pan and Cao, 2011; Tsai } \\
\text { and Yeh, 2010; Udo et al., 2010 }\end{array}$ \\
\hline
\end{tabular}

ISSN: 07I 8-2724. (http://www.jotmi.org) Journal of Technology Management \& Innovation (C) Universidad Alberto Hurtado, Facultad de Economía y Negocios. 


\begin{tabular}{|c|c|c|}
\hline & $\begin{array}{l}\text { Service Marketing Quarterly; Human Factors and Ergonomics } \\
\text { in Manufacturing \& Service Industries; Advances in EECM; } \\
\text { Behaviour \& Information Technology; Computers \& Educa- } \\
\text { tion; Computers in Human Behaviour (4); European Journal } \\
\text { of Marketing; Expert Systems with Applications (2); Innova- } \\
\text { tion Management and Industrial Engineering; International } \\
\text { Conference on MultiMedia and Information Technology; } \\
\text { International Conference on Information Management; Inter- } \\
\text { national Conference on Management of e-Commerce and e- } \\
\text { Government; International Journal Human-Computer Studies; } \\
\text { International Journal of Retail \& Distribution Management; } \\
\text { International Journal of Information Management; Journal } \\
\text { of Business Research (2); Journal of Computer Information } \\
\text { Systems; Journal of Computer-Mediated Communication } \\
\text { (2); Journal of Direct, Data and Digital Marketing Practice; } \\
\text { Journal of Hospitality and Tourism Technology; Journal of } \\
\text { Promotion Management; Journal of Retailing and Consumer } \\
\text { Services; Online Information Review; Psychology \& Market- } \\
\text { ing; Telecommunications Policy }\end{array}$ & $\begin{array}{l}\text { Oghazi et al., 2012; Lee et al., 2011; Al- } \\
\text { Maghrabi and Dennis, 2011; Chang, } \\
\text { 2010; Chen and Chen, 2011; Chiu et } \\
\text { al., 2009; Di Pietro and Pantano, 2012; } \\
\text { Di Pietro et al., 2012; Du et al., 2010; } \\
\text { Han and Jin, 2009; Ha and Stoel, 2009; } \\
\text { Hausman and Siekpe, 2009; Hong et } \\
\text { al., 2011; Hu et al., 2009; Jiang, 2009; } \\
\text { Kang and Lee, 2010; Kim and For- } \\
\text { sythe, 2009; Kim and Oh, 2011; Lee } \\
\text { and Chang, 2011; Lee and Chen, 2010; } \\
\text { Li et al., 2012; Liu and Forsythe, in } \\
\text { press; Liu and Li, 2011; Mäntymäki } \\
\text { and Salo, 2011; Oh et al., 2009; Oum } \\
\text { and Han, 2011; Shin, 2009a; Shin, } \\
\text { 2009b; Teo and Noyes, 2011; Tseng } \\
\text { and Lo, 2011; Yu Jang and Noh, 2011 }\end{array}$ \\
\hline Trust & $\begin{array}{l}\text { The Service Industries Journal; Advances in EECM; Comput- } \\
\text { ers in Human Behaviour (3); Decision Support Systems; Ex- } \\
\text { pert Systems with Applications; IEEE International Technol- } \\
\text { ogy Management Conference (2); Industrial Management \& } \\
\text { Data Systems; Information \& Management (2); Information } \\
\text { Systems Frontiers; International Conference on MultiMedia } \\
\text { and Information Technology; International Conference on } \\
\text { Management of e-Commerce and e-Government; Interna- } \\
\text { tional Journal of Human-Computer Studies; International } \\
\text { Journal of Information Management (3); International Jour- } \\
\text { nal of Retail \& Distribution Management; Journal of Applied } \\
\text { Social Psychology; Journal of Business Research (3); Journal } \\
\text { of Consumer Marketing; Journal of Promotion Management; } \\
\text { Journal of Research in Interactive Marketing; Online Informa- } \\
\text { tion Review; Psychology \& Marketing; Technovation }\end{array}$ & $\begin{array}{l}\text { Dimitriadis \& Kyrezis, 2011; Al- } \\
\text { Maghrabi and Dennis, 2011; Al-So- } \\
\text { mali et al., 2009; Alsajjan and Dennis, } \\
\text { 2010; Chang et al., 2011; Chiu et al., } \\
\text { 2009; Chiu et al., 2010a; Choe et al., } \\
\text { 2009; Chong et al., 2012; Doong et al., } \\
\text { 2011; Faqih, 2012; Ha and Stoel, 2009; } \\
\text { Han and Jin, 2009; Jiang, 2009; Li and } \\
\text { Yeh, 2010; Li et al., 2012; Lorenzo- } \\
\text { Romero et al., 2011; Luo et al., 2010; } \\
\text { Oh et al., 2009; Oum and Han, 2011; } \\
\text { Palvia, 2009; Shin, 2009a; Taylor and } \\
\text { Strutton, 2010; Thomas and Veloutsou, } \\
\text { 2011; Wei et al., 2009; Wu, 2010; Wu } \\
\text { et al., 2011; Yoon, 2009; Yousafzai et } \\
\text { al., 2010; Yu Jang and Noh, 2011 }\end{array}$ \\
\hline
\end{tabular}

Table 2. Details of the contributions associated with each identified variable

\section{Consumer's perception of technology safety and cost}

An important line of inquiry emerging from our analysis concerns the consumers' perception of the technology features, in terms of perceived security, perceived cost, perceived risk and trust. In this area, a set of distinctive features that consumers attribute to the new technology converges, in order to deeply understand how to design a new system in order to influence clients' beliefs towards the effective usage.

Perceived risk has been defined as the consumer's perceptions of the uncertainty and the possible undesirable con- sequences of using the system (Lee 2009; Tanakinjal et al. 2010). For instance, people may feel a certain level of risk when purchasing a product through a new technology (i.e. automatic payment via mobile phones), because this usage may increase the vulnerabilities, by causing inhibiting aspects to consumers' eagerness to participate in shopping activities (Lee 2009). Especially in the online channel, consumer's risk perceptions and concerns are primarily related to aspects that may have undesirable consequences upon the overall safety of the whole system, such as (i) problems related to involving the privacy and security of personal information, (ii) the security of online transaction systems and (iii) the uncertainty of the final product quality. 
Based upon past empirical studies (Lee 2009; Tanakinjal et al. 2010; Gupta and Xu 2010), perceived risk is reported to be an impending factor for consumers to engage online shopping and it negatively influences the behavioural intention to use online channel for purchases. Hence, this variable is strictly connected to the perceived security. Although some authors analysed to what extent the level of perceived security differs from the effective security of the system (Shin 2009a) by showing its effect on trust and intention to use the technology, perceived security can be defined as the degree to which a consumer believes that using that technology will be secure (Chiu et al. 2009; Du et al. 2010; Han and Jin 2009; Muller-Seitz et al. 2009; San Martin Guitiérrez et al. 2010; Shin 2009a; Taylor and Strutton 2010). In particular, perceived security represents a threat that creates circumstances, condition, or event that may cause economic hardship to data or network resources in the form of destruction, disclosure, modification of data, denial of service and/ or fraud, waste and abuse (Kalakota and Whinston 1997). In the online scenario, security threats usually occur at the network level (the server), the communication channel or the user's personal computer (the client). Indeed, Godwin (200I) and Liu and Forsythe (20II) reported that security concerns were found to be the major barrier to Internet shopping. Due to the uncertainty involved in purchasing processes, perceived security is important especially in the context of online monetary transactions and when customer has no experience with the technology (Schierz et al. 2010; Yoon 20I0), such as in the case of new online banking services (Benamati et al. 2010; Choe et al. 2009; Han and Jin 2009; Hu et al. 2009; Jiang et al. 2009; Lee 2009; Liu and Forsythe 20 II; Luo et al. 2010; San Martin Gutiérrez et al. 20I0; Shen and Chiou 20 I0;Taylor and Strutton 20 I0; Tsai and Yeh 2010; Udo et al. 2010).

Perceived cost is strictly linked to the above-mentioned variables, due to its role on the consumer's attitude towards the usage of a new technology (Choe et al. 2009; Du et al. 20 I0; Kim and Han 20I I; Kim et al. 20 I I; Shin et al. 2009a, b; Sun et al 2009; Sun et al. 2010; Tseng and Lo 201 I;Wei et al. 2009). In fact, if consumer considers high the cost for using the system, he/she will be reluctant to the actual use. Thus the high cost of value-added service might negative affect his/her intention to adopt the technology. The ambiguous and immature legal environment has also heightened the level of uncertainty associated with Internet shopping channel. Similarly, the lack of face-to-face interactions though channel increases the level of uncertainty, insecurity, anonymity, lack of control, and potential opportunism. These aspects contribute to intensify dramatically the impact of trust especially in the online domain. Therefore, the development of trust mechanism is compulsory for online shopping setting in order to enhance the positive perception of consumers toward online shopping channels and to ensure the continued growth of the channel (Di Pietro et al., 20I2). In fact, trust has been found to have also a positive effect on the intention to purchase online (der Heijden et al. 2003). Therefore, trust plays a key role for customers' shopping decisions. For these reasons, it was successfully incorporated within the TAM structure in shopping setting (Beugelsdijk et al. 2004; Zak and Knack 200I).

Past studies consider trust as an antecedent of ease of use and perceived usefulness (Pavlou 2003; Sun and Han 2002); whereas other ones (Kim et al. 2008) argued that perceived ease of use has a direct positive influence on trust because it can support consumers' sense of loyalty towards the webbased systems.

According to literature (Al-Somali et al. 2009; Alsajjan and Dennis 2010; Chiu et al. 2009; Chiu et al. 2010b; Choe et al. 2009; Doong et al. 20I I; Han and Jin 2009; Ha and Stoel 2009; Jiang et al. 2009; Li and Yeh 2010; Luo et al. 20 I0; Oh et al. 2009; Palvia 2009; Shin 2009a; Taylor and Strutton 2010; Wei et al. 2009; Wu 2010; Yoon 2009; Yousafzai et al. 2010), trust is a key factor for retail process, with emphasis on econtext, where the exchange relationships between client and vendor is characterized by uncertainty, dependence and risk. Especially in these environments consumer is unable to physically examine products, evaluate seller response, and has access to limited information, thus he/she needs resources to reduce the involved uncertainty in transactions. For this reason, the store/brand reputation influences trust and perceptions about the channel in terms of virtual seller, virtual store, store website perception which affects his/her trust in the seller (Chiu et al. 20I0a,b; Alsajjan and Dennis 2010; Chiu et al. 2010). Furthermore, it affects also consumer satisfaction emerging from the experience with the technology (Li and Yeh 2010).

\section{Consumer's personal traits}

Another important aspect involved in consumer's acceptance of technology-based innovations in the stores concerns users' personal traits, such as skills and abilities. In particular, these concern the self-efficacy and the behavioural control, which emerge as variables able to influence consumers' decision to use a certain system. In particular, self-efficacy represents consumer's judgement of own capabilities to perform certain behaviours and it is strictly linked to the behavioural control (or controllability) (Al-Somali et al. 2009; Hernandez et al. 2009a, b, 20I0; Irani et al. 2009; Kim et al. 20I I; Lee and Chen 2010; Luo et al. 2010; Shin 2009a; Sun et al. 2009). The determinants of self-efficacy are typically found in traits of the individual adopter, such as experience, personal skills and education (Kaseniemi and Rautiainen 2002). There is experimental evidence supporting the causal flow from computer self-efficacy to system-specific perceived ease of use. 
The link is justified on the fact that in the absence of a direct system experience, the confidence in individual's technology related abilities and knowledge can be expected to serve as the basis for a personal judgment about how easy or hard a new system will be to use.

Hence, self-efficacy has been found to affect technology usage also through its effect on the emotional state of the user by, for example, reducing his computer anxiety and increasing behavioural control (Koufaris 2002). Thus, computer selfefficacy relates to judgments about personal skills with benefits for the spontaneity of the individual while interacting with the system (Al-Somali et al. 2009).

Behavioural control has been defined as human control over specific action or environment (Ajzen 2002; Novak et al. 2000). In particular, it refers to individual's perceptions of their ability to perform a given behaviour (Novak et al. 2000). Hence, it is determined by the total set of accessible control beliefs about the presence of factors that may facilitate or obstruct performance of the behaviour (Jayasingh and Eze 2009). In fact, this variable motivates consumers to use the technology (Chen 20 I0; Jayasingh and Eze 2009; Jiang et al. 2009; Kim et al. 20 I I; Lee 2009; Lee and Sun et al. 20 I0; Mathwick et al. 2010; Shin 2009a; Sun et al. 2009; Yousafzai et al. 2010) because consumers who need high control are more willing to use the technology that involves them in any decision making process (Di Pietro et al. 20I2). Already Mathieson in 1991 found that control was as a stronger determinant of consumers' attitudes, even if he only examined the perceived control as the construct of TAM without effectively incorporating the concept into the model.

Due to the characteristics of online retail context, consumers are subjected to more influences in the virtual store where they are able to interact with an adaptive environment, as a consequence an adaptive and interactive scenario is more appealing for consumers, with benefits for the decision-making process (Pantano and Servidio 2012).

\section{Social pressure}

Due to the social pressure in using a particular technology, consumers are subjected to the influence of others with consequences on their attitude towards the usage of a new system (Al-Somali et al. 2009; Du et al. 20 10; Irani et al. 2009; Jayasingh and Eze 2009; Pai and Tu 20I I; Shin 2009a,b;Wei et al. 2009; Wu 20 I0: Di Pietro et al. 2012). Hence, a third area of inquiry on variables influencing consumers' decision to adopt a technology includes the external impressions that people are subject to.These refer to the social influence and to the subjective norms.
Since influence from peers, family, and even the media such as television might influence users to employ a certain technology, social influence has been included in TAM as an important variable affecting the intention to use the new system. In fact, through the influence of others (i.e. through word of month), an individual will easily become aware of the advantages of using a particular technical innovation. In particular, social influence represents the degree to which an individual considers important that others believe he or she should use an innovation (Chong at al. 2010). It reflects a normative character in line with variables such as the subjective norm (Wang et al. 2009). Indeed, several studies have suggested that this influence is a critical element in understanding innovation diffusion (Venkatesh et al. 2003; Yq et al. $20 \mathrm{II}$ ), and it has been referred also as an essential motivator of perceived usefulness (Yq et al. 20l I).

Subjective norms are defined as consumers' perception of whether other people believe they should engage certain behaviour (Pai and Tu 20II). The Theory of Planned Behaviour (TPB) (Ajzen 199I) already identified the subjective norms as key variable for explaining the consumer intention to perform a specific behaviour, as well as the attitude toward the behaviour and perceived behavioural control (Casalò et al. 2010). These norms represent the expectations of other people regarding performing a particular behaviour (Alsajjan and Dennis 2010; Casalò et al. 2010; Chang and Chang 2009; Kim et al. 20I I; Lee 2009; Lee and Chen 2010; Schierz et al. 2010), thus they explain to what extent a person is influenced by the perception of his/her behaviour by reference people such as family, friends, partner and others.

According to previous studies (Bhattacherjee 2000; Hung et al. 2003), two other concepts are combined to generate the subjective norms: external influence and interpersonal influence. External influence includes the mass media reports, expert opinions, and other non-interpersonal influences. Since consumers could be directly approached by the persuasive advertising of terminal vendors and operators, interpersonal influence is the influence of others in developing norms that the usage of a particular technology is expected. It has been suggested important especially for explaining the adoption of communication technologies (LaRose and Eastin 2002). It refers to word -of - mouth influence by reference group and it includes friends, superiors and IT experts (Di Pietro et al. 2012).

\section{Hedonic value}

Finally, another stream of research emerges on the study of Technology Acceptance Model, which is strictly linked to the hedonic value emerging by the technology usage, in terms of enjoyment and satisfaction. 
Enjoyment can be considered the degree to which consumer perceives a certain technology as pleasant (Venkatesh 2000). This represents an emotional state or an intrinsic motivation capable of stimulating consumers in continuing such behaviours (Chang 2010; Chiu et al. 2009; Du et al. 2010; $\mathrm{Ha}$ and Stoel 2009; Han and Jin 2009; Hausman and Skiepe 2009; Hu et al. 2009; Jiang et al. 2009; Kang and Lee 2010; Kim and Forsythe 2009; Liu and Forsythe 20I I; Oh et al. 2009; Tseng and Lo 20II; Shin et al. 2009a,b). Much emphasis on enjoyment has been discussed and applied to previous research on online retailing (Pantano and Corvello 2010). A huge deal of research indicated the strong positive effects of enjoyment on attitudes toward online retailers (Childers et al. 200 I; Eighmey and McCord 1998; Heijden and Verhagen 2004; Lee et al. 2005; Mathwick et al. 200I). In fact, several researches carried out that an entertaining context has a stronger impact on consumers' satisfaction (Soderlund and Julander 2009) and motivates people in using online technologies (Cheung et al. 20 I I; Ha and Stoel 2009; Lee et al. 2005). Hence, consumer who exhibits pleasure while shopping makes a more extensive use of that stores (virtual or physi$\mathrm{cal}$ ones) in terms of longer and more frequent visits ( $\mathrm{Ha}$ and Stoel 2009). In particular, Childers et al. (200I) figured out the strong effects of enjoyment on attitudes toward online grocery shopping and suggested that creating interactive features would differentiate online shopping channel from the physical one; whereas Lee et al.'s (2005) study suggested that richer technology leads to higher enjoyment for achieving a stronger influence on consumers' attitudes toward online retailers. Hence, enjoyment is positively related to user's satisfaction with specific technology products (Pantano and Servidio 2012;Woszczynski et al. 2002). For this reason, enjoyment emerges as causal variable on perceived utility and perceived ease of use.

While enjoyment is an emotional state, satisfaction is a feeling emerging from the consumers' experience with a product (Tseng and Lo 20II; Udo et al. 20l0). This construct measures the assessments of the experience including overall pleasure related with the service received and it can be considered as one of the most significant predictors of their subsequent behaviour (Hernandez et al. 2009a, 2009b, 2010; Kang and Lee 2010; Palvia 2009; Taylor and Strutton 2010; Yoon 2010).

Satisfaction is critical for establishing long-term client relationships and, consequently, is significant in sustaining profitability. Customers' satisfaction is the consequence of experiences during various purchasing stages: (I) needing something, (2) gathering information about it, (3) evaluating purchasing alternatives, (4) actual purchasing decision, and (5) post purchasing behaviour. During information gathering, the new technologies offer consumers extensive benefits, due to the reducing of searching costs, increasing of conveni- ence and choices (Bakos 1998). Yet, online consumers are dependent upon the technology tools information as a replacement for physical contact with salespersons (McKinney et al. 2002). As a result, consumers make inferences about the attractiveness of a product based on: (I) information provided by retailers, and (2) design elements of the new technology such as ease and fun of navigation (Wolfinbarger and Gilly 200I).

\section{Discussion and research agenda}

The present study aims at integrating the researches on consumer acceptance of new technologies in retailing into a unified model which includes the main elements of the previously extensions of Technology Acceptance Model (TAM). The first step was to identify the most recent researches on consumer acceptance of technologies in online and offline points of sale, whereas the second one was to figure out the determinants of intention and usage of the technology. Afterwards, these constructs were empirically compared in order to understand the links across variables and studies. As result, the conceptual and empirical similarities were used to propose a unified model that might provide a basic framework for future researches in this direction. In particular, the review carried out in the previous sections show that, so far, TAM has been subject of studies for several disciplines, focusing on different perspectives, and exploiting different important variables not included in the initial model developed by Davis in 1989. Due to the numerous intersections among different areas of the research, we underline some lines for future inquiries across the different disciplines, which would be integrated in a common approach in order to advance our knowledge of the phenomenon from an integrated perspective. These suggestions figure out a promising research agenda (Table 3).

\section{Psychological traits}

Investigation of how consumers respond to technology introduction has traditionally carried out by technology adoption researches. In fact, many studies highlighted the importance of users' psychological traits for predicting the effective acceptance of the new technology. The supposition that those traits are variables of TAM finds considerable support in the attitude-behaviour models from the socialpsychology literature (Kim et al. 20I I).

Hence, the effective usage of a new system requires some actions by users, thus the design of some technologies could be "better" than others by requiring less mental effort. We believe that additional empirical works are useful to establish more in detail what drives the consumers capacity to adopt a certain technology, as well as to what extent the personal traits influence this adoption and under what 


\begin{tabular}{|c|c|c|}
\hline Areas of research & Research topic & Core research questions \\
\hline $\begin{array}{l}\text { Psychological } \\
\text { traits }\end{array}$ & $\begin{array}{l}\text { Identification of consum- } \\
\text { ers skills }\end{array}$ & $\begin{array}{l}\text { What are consumers skills requested for the actual usage of a new technol- } \\
\text { ogy? How do personal traits influence consumers' technology adoption? } \\
\text { Under what conditions are consumers more willing to accept the technol- } \\
\text { ogy? Under what conditions are consumers satisfied to use the technology? } \\
\text { How do consumer's expectations influence technology adoption? }\end{array}$ \\
\hline Technical traits & $\begin{array}{l}\text { Identification of consum- } \\
\text { ers needs and requests }\end{array}$ & $\begin{array}{l}\text { How technology has to be designed to reflect consumers' need? How does } \\
\text { information management influence technology adoption? How can tech- } \\
\text { nology reply to consumers' request of entertaining? How can technology } \\
\text { enhance consumers' shopping activity? How will store layout change ac- } \\
\text { cording to technology adoption? How can technology be designed to allow } \\
\text { access privileges or security and privacy? }\end{array}$ \\
\hline $\begin{array}{l}\text { Innovation co- } \\
\text { creation process }\end{array}$ & $\begin{array}{l}\text { Understanding oppor- } \\
\text { tunities, strengths and } \\
\text { modalities of consumers } \\
\text { involvement in the co- } \\
\text { creation process of retail } \\
\quad \text { innovation }\end{array}$ & $\begin{array}{l}\text { How innovations for retailing might be designed by consumers? How does } \\
\text { consumers' involvement in co-creation influence technology adoption and } \\
\text { retail process? How will retail process change according to these innova- } \\
\text { tions? How will organization reply to these innovations in the retail pro- } \\
\text { cess? }\end{array}$ \\
\hline Adoption results & $\begin{array}{l}\text { Contextual conditions } \\
\text { and profitability of tech- } \\
\text { nology acceptance }\end{array}$ & $\begin{array}{l}\text { Which kind of technology would be more beneficial to a firm and under } \\
\text { what conditions? Are certain types of technologies more or less appropriate } \\
\text { to certain types of products in sale? What factors do influence the capacity } \\
\text { to profit from innovation capabilities in the development of technical solu- } \\
\text { tions for retailing? What makes a technology-driven strategy sustainable } \\
\text { over time? To what extent does the development/introduction of new tech- } \\
\text { nologies require new retailing business models? }\end{array}$ \\
\hline
\end{tabular}

Table 3. Issues for future research on advanced technologies management for retailing

conditions consumers are more willing to accept the new system (i.e. store atmosphere, layout, etc.). In fact, the introduction of new technologies in the stores can substitutes the face-to-face contact with a real seller (Kang and Lee 2010; Oh et al. 2009; Shin et al 2009b; Udo et al. 2010), for this reason trust emerges as the most motivating factor in the adoption. Since satisfaction and expectations towards technology usage influence consumers' acceptance, another interesting inquiry of research concerns the conditions that can positively influence consumers' satisfaction towards the technology usage and fulfil the expectations. How the technology will solicits consumers' emotion to obtain a certain behavioural response?

Other issues may investigate their response towards the introduction of technologies like the self-service ones that do not require the presence of a physical vendor. As a consequence, the client-vendor relationship will dramatically change and will need to be further investigated.
Moreover, the results show a still a limited number of works on consumers' innovativeness in retail context, that take into account the personal attitude towards innovation for explaining innovation acceptance and diffusion among vendors; thus the level of innovativeness of the decision-maker would explain to what extent innovations will be introduced in the traditional points of sale. Similarly, both consumers' and retailers expectations towards a technology-based innovation are able to influence the adoption and diffusion process, thus these aspects need to be further investigated to develop also new diffusion models.

\section{Technical traits}

Future research may try to investigate how individual tastes and preferences guide the development of technologies that can be more accepted by consumers. In fact, the success of these technologies is the result of an efficient design and human widespread tastes and preferences. The system-related

ISSN: 07 I8-2724. (http://www.jotmi.org) 
technical traits will enhance usability of the system because users will be able to perform their tasks quickly. Furthermore, if the system is user friendly, user may feel a more a greater control over the system, with benefits on the selfefficacy toward the system usage.

Technical traits are critical for at least two interrelated reasons: (i) minimization of (consumers') initial resistance to a new system, and (ii) providing a realistic view of the system in order to provide potential consumers both an accurate perception regarding system features and how the system may help them performing their purchase decision process (Venkatesh 2012). The research in this direction would focus on the interaction and input modalities, by also exploiting and adapting the recent developments in the game industry. Since the technical innovations in retailing are becoming increasingly complex and central for consumer's decision making and the adoption of new disruptive (radical) systems substantial changes the store layout dramatically, the technology-based innovations in the points of sale are subject to severe resistance by consumers. Hence the information about the new technologies plays a role in consumer's intention to use. Due to the risk related to the information overload (Chen et al. 2009), future research would focus on how to exploit the new technologies for increasing the provided information and make them customized on consumers' needs, by avoiding the risk of overload.

Other key questions concerning the technology development are: How can technology enhance consumers' shopping activity? How will store layout change according to technology adoption? How can technology be designed to allow access privileges or security and privacy?

\section{Innovation co-creation process}

The current researches in involving users in the co-creation process forces retailer to consider the opportunities emerging from the consumers' involvement in the innovation development (Alexander et al. 2009). In fact, if they are active participants in the development process, they will be more able to adopt the emerging innovation, which will be highly customized on their needs and preferences. For instance, the development of innovative adaptive technologies and the improvements of self-service technologies would be able to maximize the acceptance of the system and emerging value for consumers. A critical issue will concern how to exploit consumers' knowledge and how to solicit their creative contribution for developing the retail process by introducing new technical solutions, and on the importance of consumers' role for innovation process.

Hence, in this scenario, new critical aspects need to be further investigated: how it will be possible to code and manage the input data emerged by consumers' involvement? What are the technologies able to better support this process? How many consumers need to be involved to have reliable and efficient data for enhancing the development process? How the firm will be able to manage consumers' input data?

\section{Adoption results}

Several evidences from research in marketing, management, innovation and technology suggested that the introduction of new technologies might affect positively the retailers' performance, with benefits for firms' profitability. In fact, due to the introduction of new technical solutions in the points of sale, consumers may feel that the new system will threaten their existing routines and habits and change the nature of their relationships with vendors, with consequences for brand/firm image.

Hence, further studies would explain more observations on to what extent the development/introduction of new technologies will require new retailing business model, and which factors will influence the capacity to profit from innovation capabilities in the development of technical solutions for retailing. Similarly, a further line of inquiry may lie in the firm's dynamic capabilities for being able to appropriate successfully all the benefits these innovations generate.

Since most of the current studies on introduction of advanced technologies in the point of sale mainly focus on the analysis of the consumers' point of view, a fine-grained comprehension of how these changes in retail business models can be carried out and co-ordinated in organizations represents a stream of research upon which further studies would rely. In particular, we suggest a punctual analysis on managerial interventions, specific management actions and policies, dynamic capabilities triggered by the introduction of these technologies for increasing the firm's profitability. In this way it will be possible to advance our knowledge on the technology adoption and diffusion among organizations, as well as to predict the future direction.

Moreover, other studies could achieve data on how to manage the innovation process in the store for defining possible frameworks for a successful adoption process and an efficient innovation-driven retailing, for instance by exploit the open innovation strategies for involving end-users in the development process (Carlsson et al. 2009).

\section{Conclusions}

While the power of Information and Communication technologies in the shopping experience increases constantly, customers' expectations also rise, by forcing retailers to fast prompt to market instability. The global usage of new tech- 
nologies will dramatically changes the interactions between consumers and retailers and requires new efficient retailing business models, as anticipated by Sorescu et al. (20I I).

In this scenario, the present work advances our knowledge on the consumers acceptance of new technologies in the points of sale, in both online and offline context, and explores the newly extended concept of Technology Acceptance Model (TAM) represents one of the most widely used models for describing an individual's acceptance of information systems. Though previous studies including review of TAM antecedents and meta-analysis, the present work has tested the applicability and the convergence of TAM relationships across various fields. This study differs from past reviews due to its attempts to develop an integrating map of TAM based on the most important variables: perceived security, perceived cost, satisfaction, self-efficacy, behavioural control, subjective norms, social influence, perceived risk, enjoyment, and trust (see Table I). We accomplished this study by identifying four main categories of TAM's variables: consumers' perception of technology safety and cost, consumer's personal traits, social pressure and hedonic value. This research unifies the theoretical perspective expressed in the current literature and includes the main variables emerging from the most recent studies in the sector, by underlying the main role played by the trust construct.

In our expectation, this study may serve as a benchmark for future researches to investigate developments in the TAM field and to record the emergence of new research areas by incorporating more newly published papers over time.

In addition, the review encompassing across different fields highlights opportunities for new integrated streams of research, by revealing powerful intersections on areas of marketing, management, computer, science, and psychology (see Table 2).

Although researches on consumers behaviour have widely acknowledged the importance of usefulness, ease of use, other opinions and enjoyment for predicting the adoption of a new technology in retail context, there is still a lack in the knowledge of how these technical innovations will change the traditional retailing business models and to what extent these ones can be co-ordinated in organizations for achieving a certain profitability.

Finally, there is the need of new researches in the concept of advanced technologies and innovation management for retailing, as well as the need of the development of deeper measurement scales which enable the components states to be verified and measured in order to make more detailed previsions on future consumer's behaviours.

\section{References}

AJZEN, I. 2002. Perceived Behavioural Control, Self-Efficacy, Locus of Control, and the Theory of Planned Behavior. Journal of Applied Social Psychology, 32, 665-683.

ALEXANDER,A., Nell, D., Bailey,A.R., and Shaw, G. 2009. The co-creation of a retail innovation: shoppers and the early supermarket in Britain. Enterprise \& Society, 10 (3), 529-558.

ALSAJJAN, B., and Dennis C. 2010. Internet banking acceptance model: Cross-market examination. Journal of Business Research, 63, 957-963.

AL-SOMALI, S.A., Gholami, R., and Clegg B. 2009.An investigation into the acceptance of online banking in Saudi Arabia. Technovation, 29, |30-|4|.

BAKOS, Y., Lucas, H. C. Jr., Oh,W., Simon, G.,Viswanathan, S., and Weber, B. 20I0.The Impact of Electronic Commerce on Competition in the Retail Brokerage Industry. Information Systems Research, I6 (4), 352-37I.

BAIER, D., and Stuber E. 20I0. Acceptance of recommendations to buy in online retailing. Journal of Retailing and Consumer Services, 17, 173-180.

BERRY, L.L., Bolton, R.N., Bridges, C.H., Meyer, J., Parasuraman,A., and Seiders, K. 2010. Opportunities for innovation in the delivery of interactive retail services. Journal of Interactive Marketing, 24, I55-167.

BEUGELSDIJK, S., de Groot, H. L., and van Schaik,A. B. 2004. Trust and Economic Growth:A Robustness Analysis. Oxford University Press, 56 ( I), I I 8-134.

BENAMATI, J., Fuller, M.A., Serva, M.A., and Baroudi, J. 2010. Clarifying the Integration of Trust and TAM in E-Commerce Environments: Implications for Systems Design and Management. IEEE Transactions on Engineering Management, 57 (3), 380-393.

BHARADWAJ, N., Walker Naylor, R. and Hofstede, F. 2009. Consumer response to and choice of customized versus standardized systems. International Journal of Research in Marketing, 26 (3), 216-227.

BHATTACHERJEE, A. 2000. Acceptance of e-commerce services: the case of electronic brokerages, IEEE Transactions on Systems, Man and Cybernetics, 30 (4), 4I I-420.

BREUGELMANS, E., and Campo, K. 20II. Effectiveness of In-Store Displays in a Virtual Store Environment. Journal of Retailing, 87 (I), 75-89. 
CARLSSON, S., Corvello, V., and Migliarese, P. (2008). Enabling open innovation: proposal of a framework supporting ICT and KMS implementation in web-based intermediaries. 17th European Conference on Information Systems (ECIS).

CASALO, LV., Flaviàn, C., and Guinalìu, M. 20I0. Determinants of the intention to participate in firm-hosted online travel communities and effects on consumer behavioural intentions. Tourism Management, 31, 898-9II.

CHANG, H.H. 20I 0.Task-technology fit and user acceptance of online auction. International Journal of Human-Computer Studies, 68, 69-89.

CHANG, G., and Caneday, L. 20I I. Web-based GIS in tourism information search: Perceptions, tasks, and trip attributes. Tourism Management, 32 (6), I 435-I 437.

CHANG, K., and Chang, C.C. 2009. Library self-service. Predicting user intentions related to self-issue and return systems. The Electronic Library, 27 (6), 938-949.

CHEN,Y.C., Shang, R.A., and Kao C.Y. 2009. The effects of information overload on consumers subjective state towards buying decision in the internet shopping environment. Electronic Commerce Research and Applications, 8 (I), 48-58.

CHEN, S.-S., Chen, H.-H., and Chen, M.-F. 2009a. Determinants of satisfaction and continuance intention towards self-service technologies. Industrial Management \& Data Systems, 109 (9), 1248-1263.

CHEUNG, C.M.K., Chiu, P.K., and Lee, M.K.O. 20I I. Online social networks:Why do students use facebook? Computers in Human Behaviour, 27(4), I337-I 343.

CHILDERS, T.L., Carr, C.L., Peck, J., and Carson, S. 200I. Hedonic and utilitarian motivations for online retail shopping behavior. Journal of Retailing, 77 (4), 5 I I-535.

CHIU,Y.-T. H., Fang, S.-C., and Tseng, C.-C. 20I0. Early versus potential adopters. Exploring the antecedents of use intention in the context of retail service innovations. International Journal of Retail \& Distribution Management, 38 (6), 443-459.

CHIU, C.M., Huang, H.Y., and Yen, C.H. 20I0a.Antecedents of trust in online auctions. Electronic Commerce Research and Applications, 9, I48-159.

CHIU, PH., Kao, G.Y.M. and Lo, C.C. 20I0b. Personalized blog content recommender system for mobile phone users. International Journal of Human-Computer Studies, 68, 496-507.
CHIU, C.M., Chang, C.C., Cheng, H.L., and Fang, Y.H. 2009. Determinants of customer repurchase intention in online shopping. Online Information Review, 33 (4), 76I-784.

CHOE, Y.C., Park, J., Chung, M., and Moon, J. 2009. Effect of the food traceability system for building trust: Price premium and buying behaviour. Information Systems Frontiers, II, 167-179.

CHONG,A.Y.L., Ooi, K.B., Lin, B.S., and Raman, M. 2009. Factors affecting the adoption level of e-commerce:An empirical study. Journal of Computer Information Systems, 50 (2), 13-22.

DAVIS, F.D. 1989. Perceived usefulness, perceived ease of use, and user acceptance of information technology. MIS Quarterly, I3, 319-340.

DENNIS, C., Newman, A., Brakus, J.J., and Wright, L.T. 2010. The mediating effects of perception and emotion: digital signage in mall atmospherics. Journal of Retailing and Consumer Services, 17 (3), 205-2I5.

DIMITRIADIS, S., and Kyrezis, N. 20II. The effect of trust, channel technology, and transaction type on the adoption of self-service bank channels. The Service Industries Journal, 3 I (8), |293-13।0.

DI PIETRO, L., Di Virgilio, F., and Pantano, E. 20I2. Social network for the choice of tourist destination:Attitude and behavioural intention. Journal of Hospitality and Tourism Technology, 3 (I), 60-76.

DOONG, H.S., Wang, H.C., and Foxall, G.R. 20I I. An investigation of consumers' web store shopping: A view of clickand-mortar company. International Journal of Information Management, 3I (3), 20I0-2I6.

DU, H., Whinston, A.B., Lu, T., and Liu, J. 2010. An empirical study of consumer adoption on mobile data services (MDS) in China. Second International Conference on MultiMedia and Information Technology, 298-30I.

EASTLICK, M. A., Ratto, C., Lotz, S. L., and Mishra, A. 2012. Exploring antecedents of attitude toward co-producing a retail checkout service utilizing a self-service technology. The International Review of Retail, Distribution and Consumer Research, 22 (4), 337-364

EIGHMEY, J., and McCord, L. 1998. Adding Value in the Information Age: Uses and Gratifications of Sites on the World Wide Web. Journal of Business Research, 4I, I87- 194. 
FISHBEIN, M., and Ajzen, I. 1975. Belief, Attitude, Intention, and Behavior: An Introduction to Theory and Research. Reading, MA:Addison-Wesley.

GODWIN, J.U. 200I. Privacy and Security concerns as a major barrier for e-commerce: a survey study. Information Management \& Computer Security, 9 (4), I65- 174.

GREENHALGH, T. and Peacock, R. 2005. Effectiveness and efficiency of search methods in systematic reviews of complex evidence: Audit of primary sources. British Medical Journal, 33I, I064-1065.

GUPTA, S., and Xu, H. 20I0. Examining the relative influence of risk and control on intention to adopt risky technologies. Journal of Technology Management \& Innovation, 5 (4), 22-37.

HA, S. and Stoel, L. 2009. Consumer e-shopping acceptance: Antecedents in a technology acceptance model. Journal of Business Research, 62, 565-57I.

HAN, L., and Jin, Y. 2009. A Review of Technology Acceptance Model in the E-commerce Environment. International Conference on Management of e-Commerce and e-Government, 28-3I.

HAUSMANN, A.V., and Siekpe, J.S. 2009. The effect of web interface features on consumer online purchase intentions. Journal of Business Research, 62, 5-13.

HERNANDEZ, B., Jimenez, J., and Martin, M.J. 2009a. Adoption Vs acceptance of e-commerce: two different decisions. European Journal of Marketing, 43 (9/10), 1232-1 245.

HERNANDEZ, B., Jimenez, J. and Martin, M.J. 2009b. The impact of self-efficacy, ease of use and usefulness on e-purchasing: An analysis of experienced e-shoppers. Interacting with Computers, 2I, I46-I 56.

HERNANDEZ, B., Jiménez, J. and Martin, M.J. 20 I0. Customer behaviour in electronic commerce:The moderating effect of e-purchasing experience. Journal of Business Research, 63, 964-97I.

HSIAO, M.H. 2009. Shopping mode choice: Physical store shopping versus e-shopping. Transportation Research Part E, 45, 86-95.

HU,Y., Sun, X., Zhang, J., Zhang, X., Luo, F., and Huang, L. 2009. A University Student Behavioural Intention Model of Online Shopping Based on TAM. International Conference on Information Management, Innovation Management and Industrial Engineering, 625-628.
HUNG, Y.H., Huang, M.L. and Chen, K.S. 2003. Service quality evaluation by service quality performance matrix. Total Quality Management, 14, 79-89.

IRANI, Z., Dwivedi, Y.K., and Williams, M.D. 2009. Understanding consumer adoption of broadband: an extension of the technology acceptance model. Journal of the Operational Research Society, 60, I322-1334.

JAYASINGH, S., and Eze, U.C. 2009. Exploring the Factors Affecting the Acceptance of Mobile Coupons in Malaysia. Eighth International Conference on Mobile Business, 329334.

JIANG, P. 2009. Consumer Adoption of Mobile Internet Services: An Exploratory Study. Journal of Promotion Management, I5, 4I8-454.

JIN, S.A. 2009. The Roles of Modality Richness and Involvement in Shopping Behaviour in 3D Virtual Stores. Journal of Interactive Marketing, 23 (3), 234-246.

KANG, Y.S., and Lee, H. 2010. Understanding the role of an IT artefact in online service continuance: An extended perspective of user satisfaction. Computers in Human Behaviour, 26, 353-364.

KALAKOTA, R., and Whinston, A. 1997. Electronic Commerce: a manager's guide. Boston:Addison-Wesley.

KASENIEMI, E., and Rautiainen, P. 2002. Mobile culture of children and teenagers in Finland. In: Katz, J.E., Aakhus, M. (Eds.), Perpetual contact. New York: Cambridge University Press.

KIM, J., and Forsythe, S. 2009. Adoption of sensory enabling technology for online apparel shopping. European Journal of Marketing, 43 (9/I0), I I0I-I I 20.

KIM, B., and Han, I. 20II.The role of utilitarian and hedonic values and their antecedents in a mobile data service environment. Expert Systems with Applications, 38, 23 I I-23 I8.

KIM, H.B., Kim, T., and Shin, S.W. 2009. Modelling roles of subjective norms and eTrust in customers' acceptance of airline B2C eCommerce websites. Tourism Management, 30, 266-277.

KIM,T., Lee, J. H., and Law, R. 2008. An empirical examination of the acceptance behaviour of hotel front office systems: An extended technology acceptance model. Tourism Management, 29, 500-5I3. 
KIM, C., Mirusmonov, M., and Lee, I. 20I0. An empirical examination of factors influencing the intention to use mobile payment. Computers in Human Behaviour, 26, 310-322.

KIM, H., and Niehm, L.S. 2009. The impact of Website Quality on Information Quality, Value, and Loyalty Intentions in Apparel Retailing. Journal of Interactive Marketing, 23 (3), 22I-233.

KIM, K.K., Shin, H.K., and Kim, B. 20I I. The role of psychological traits and social factors in using new mobile communication services. Electronic Commerce Research and Applications, 10 (4), 408-4I7.

KOUFARIS, M. 2002. Applying the Technology Acceptance Model and Flow Theory to Online Consumer Behavior. Information Systems Research, 13 (2), 205-223.

KOWATESCH, T., and Maass, W. 20I0. In-store consumer behaviour: How mobile recommendation agents influence usage intentions, product purchases, and store preferences. Computers in Human Behaviour, 26, 697-704.

LAROSE, R., and Eastin, M. S. 2002. Is on-line buying out of control? Electronic commerce and consumer self- regulation. Journal of Broadcasting and Electronic Media, 46 (4), 549-564.

LEE, M., Cheung, C., and Chen, Z. 2005. Acceptance of Internet-based learning medium: the role of extrinsic and intrinsic motivation. Information and Management, 42, I095-I I 04.

LEE, M.C. 2009. Factors influencing the adoption of internet banking: An integration of TAM and TPB with perceived risk and perceived benefit. Electronic Commerce Research and Applications, 8, I30-14I.

LEE, S.M., and Chen, L. 2010. The impact of flow on online consumer behaviour. Journal of Computer Information Systems, 4 , I- 10.

LEE W., Chiu Y.T.H., Liu C.-C., and Chen C.-Y. 20I I.Assessing the effects of consumer involvement and service quality in a self-service setting. Human Factors and Ergonomics in Manufacturing \& Service Industries, 2 I (5), 504-5I5.

LI, Y.M. and Yeh, Y.S. 20I0. Increasing trust in mobile commerce through design aesthetics. Computers in Human Behaviour, 26, 673-684.

LIU, C., and Forsythe, S. 20II. Examining drivers of online purchase intensity: Moderating role of adoption duration in sustaining post-adoption online shopping. Journal of Retailing and Consumer Services, 18 (I), I0I-109.
LIU,Y., Li, H., and Carlsson, C. 20 I0. Factors driving the adoption of m-learning: An empirical study. Computers \& Education, 55, $1211-1219$.

LIU, S.H., Liao, H.L., and Pratt, J.A. 2009. Impact of media richness and flow on e-learning technology acceptance. Computers \& Education, 52, 599-607.

LIU, S.-F., Huang, L.-S., and Chiou, Y.-H. 2012. An integrated attitude model of self-service technologies: evidence from online stock trading systems brokers. The Service Industries Journal, 32 (I I), I823-I835.

LUO, X., Li, H., Zhang, J., and Shim, J.P. 20I0. Examining multi-dimensional trust and multi-faceted risk in initial acceptance of emerging technologies:An empirical study of mobile banking services. Decision Support Systems, 49, 222-234.

MATHIESON, K. 199I. Predicting user intentions: Comparing the technology acceptance model with the theory of planned behavior. Information Systems Research, 2 (3), I73191.

MATHWICK, C., Wagner, J., and Unni, R. 20I0. ComputerMediated Customization Tendency (CMCT) and the Adaptive e-Service Experience. Journal of Retailing, 86 (I), II-2I.

MCKINNEY, V., Yoon, K., and Zahedi F. 2002. The Measurement of Web-Customer Satisfaction: An Expectation and Disconfirmation Approach. Information System Research, 13 (3), 296-3I5.

MULLER-SEITZ, G., Dautzenber, K., Creusen, U., and Stromereder, C. 2009. Customer acceptance of RFID technology: Evidence from the German electronic retail sector. Journal of Retailing and Consumer Services, 16, 31-39.

NOVAK, T. P., Hoffman, D. L., and Yung, Y.F. 2000. Measuring the Customer Experience in Online Environments:A Structural Modelling Approach. Marketing Science, 19 (I), 22-42.

OCHI, P., Rao, S., Takayama, L. and Nass, C. 20I0. Predictors of user perceptions of web recommender systems: How the basis for generating experience and search product recommendations affects user responses. International Journal of Human-Computer Studies, 68, 472-482.

OGHAZI, P., Mostaghel R., Hultamn M., and Parida V. 2012. Antecedents of technology-based self-service acceptance: a proposed model. Service Marketing Quarterly, 33, 195-2 10.

OH, S.H., Kim, Y.M., Lee, C.W., and Shim, G.Y. 2009. Consumer Adoption of Virtual Stores in Korea: Focusing on the Role of Trust and Playfulness. Psychology \& Marketing, 26 (7), 652-668. 
PAI, J.C. and Tu, F.M. 20II. The acceptance and use of customer relationship management (CRM) systems: An empirical study of distribution service industry in Taiwan. Expert Systems with Applications, 38, 579-584.

PALVIA, P. 2009. The role of trust in e-commerce relational exchange: A unified model. Information \& Management, 46, 213-220.

PANTANO, E., and Laria, G. 2012. Innovation in retail process: from consumers' experience to immersive store design. Journal of Technology Management \& Innovation, 7 (3), 198-205.

PANTANO, E., and Corvello, V. 20I0. Digital contents management for improving consumers' experience. International Journal of Digital Content Technology and its Application, 4 (7), 8-10.

PANTANO, E., and Servidio, R. 2012. Modelling innovative points of sales through virtual and immersive technologies. Journal of Retailing and Consumer Services, 19 (3), 279-286.

PANTANO, E., and Viassone, M. 20I2. Consumers' expectation of innovation: shift retail strategies for more attractive points of sale. International Journal of Digital Content Technology and its Applications, 16 (2I), 455-46I.

PAVLOU, P.A. 2003. Consumer Acceptance of Electronic Commerce: Integrating Trust and Risk with the Technology Acceptance Model. International Journal of Electronic Commerce, 7 (3), I0I-I34.

PUCCINELLI, N.M., Goodstein, R.C., Grewal, D., Price, R., Raghubir, P. and Stewart, D. 2009. Customer Experience Management in Retailing: Understanding the Buying Process. Journal of Retailing, 85 (I), I5-30.

RAVASI, D. and Stigliani, I. Product design: a review and research agenda for management studies. International Journal of Management Reviews, I4 (4), 464-488.

REINDERS, M.J., Dabholkar P.A. and Frambach, R.T. 2008. Consequences of Forcing Consumers to Use TechnologyBased Self-Service. Journal of Service Research, II (2), I07123.

SAN MARTIN GUTIERREZ, S., Camarero Izquierdo, C. and San José Cabezudo, R. 20I0. Product and channel-related risk and involvement in online contexts. Electronic Commerce Research and Applications, 9, 263-273.
SCHIERZ, P.G., Schilke, O., and Wirtz, B.W. 20I0. Understanding consumer acceptance of mobile payment services: An empirical analysis. Electronic Commerce Research and Applications, 9, 209-216.

SHEN, C.C., and Chiou, J.S. 20I0. The impact of perceived ease of use on Internet service adoption: The moderating effects of temporal distance and perceived risk. Computers in Human Behaviour, 26, 42-50.

SHIN, D.H. 2009a. Towards an understanding of the consumer acceptance of mobile wallet. Computers in Human Behaviour, 25, I343-I354.

SHIN, D.H. 2009b. An empirical investigation of a modified technology acceptance model of IPTV. Behaviour \& Information Technology, 28 (4), 36I-372.

SIMMONS, K., and Istook, C.L. 2003. Body Measurement techniques: a Comparison of 3D Body Scanning and Anthropometric Methods for Apparel Applications. Journal of Fashion Marketing and Management, 7 (3), 306-332.

SODERLUND, M., and Julander, C.R. 2009. Physical attractiveness of the service worker in the moment of truth and its effects on customer satisfaction. Journal of Retailing and Consumer Services, 16 (3), 216-226.

SORESCU, A., Frambach, R.T., Singh, J., Rangaswamy, A. and Bridges, C. 20I I. Innovations in retail business models. Journal of Retailing, 87S (I), S3-SI6.

SUN, B., and Han, I. 2002, Effect of trust on customer acceptance of Internet banking. Electronic Commerce Research and Applications, I, 247-263.

SUN, Q., Hao, C., and Jianxin, Y. 20I0. Factors Influencing the Adoption of Mobile Service in China:An Integration of TAM. Journal of Computers, 5 (5), 799-806.

SUN, Q., Wang, C., and Cao, H. 2009. An Extended TAM for Analyzing Adoption Behavior of Mobile Commerce. Eighth International Conference on Mobile Business, 52-56.

TANAKINJAL, G.H., Deans, K.R., and Gray, B.J. 20I0. Third Screen Communication and the Adoption of Mobile Marketing: A Malaysia Perspective. International Journal of Marketing Studies, 2 (I), 36-47.

TAYLOR, D., and Strutton, D. 2010. Has e-marketing come of age? Modelling historical influences on post-adoption era Internet consumer behaviours. Journal of Business Research, 63, 950-956. 
TSAI, Y.C., and Yeh, J.C. 20I0. Perceived risk of information security and privacy in online shopping: A study of environmentally sustainable products. African Journal of Business Management, 4(I8): 4057-4066.

TSENG, F.M., and Lo, H.Y. 20I I. Antecedents of consumers' intentions to upgrade their mobile phones. Telecommunications Policy, 35, 74-86.

UDO, G.J., Bagchi, K.K., and Kirs, P.J. 20I0. An assessment of customers' e-service quality perception, satisfaction and intention. International Journal of Information Management, $30,48 \mathrm{I}-492$.

VAN DER HEIJDEN, H.,Verhagen, T. and Creemers, M. 2003. Understanding online purchase intentions: contributions from technology and trust perspectives. European Journal of Information Systems, I2, 4I-48.

VAN DER HEIJDEN, H.,, H., and Verhagen, T. 2004. Online store image: conceptual foundations and empirical measurement. Information \& Management, 4I (5), 609-6I7.

VENKATESH, V. 2000. Determinants of Perceived Ease of Use: Integrating Control, Intrinsic Motivation, and Emotion into the Technology Acceptance Model. Information Systems Research, II (4), 342-365.

VENKATESH, V., Morris, M.G., Davis, G.B., and Davis, F.D. 2003. User Acceptance of Information Technology:Toward a Unified View. MIS Quarterly, 27 (3), 425-478.

VENKATESH, V., Thong J.Y.L., and Xu X. 20I2. Consumer acceptance and use of information technology: extending the unified theory of acceptance and use of technology. MIS Quarterly, 36 (I), I57-I78.

VIEIRA,V.A. 20I0.Visual aesthetics in store environment and its moderating role on consumer intention. Journal of Consumer Behaviour, 9, 364-380.

VIJAYARAMAN, B., Osyk, B.A., Chavada, D. 2008. An exploratory study of RFID adoption in the paperboard packaging industry. Journal of Technology Management \& Innovation, 3 (4), 95-II0.

VRECHOPOULOS, A., and Atherinos, E. 2009. Web banking layout effects on consumer behavioural intentions. International Journal of Bank Marketing, 27 (7), 524-546.

WAN ISMAIL, W.K., Chan, P.H.K., Buhari, N., Muzaini, A. 2012. Acceptance of smartphone in enhancing patient-caregivers relationship. Journal of Technology Management \& Innovation, 7 (3), 7I-79.
WEI, T.T., Marthandan, G., Ching, A.Y.L., Oi, K.B. and Arumugam, S. 2009. What drives Malaysian m-commerce adoption? An empirical analysis. Industrial Management \& Data Systems, 109 (3), 370-388.

WENG Z., Liu,D., and Zhao D. 2012, Study of customer productivity-using technology based self-service options. International Joint Conference on Service Sciences, IEEE, 30I-306.

WILLOW, C. 2010. Third-generation display technology: nominally transparent material. Journal of Technology Management \& Innovation, 5 (4), 108-120.

WOLFINBARGER, M., and Gilly, M. 200I. Shopping online for freedom, control, and fun. California Management Review, 43 (2), 34-55.

WOSZCZYNSKI, A.B., Roth, P.L., and Segars, A.H. 2002. Exploring the theoretical foundations of playfulness in computer interactions. Computers in Human Behavior, 18 (4), 369-388.

WU, L.T. 2010.An Empirical Study on Factors Affecting Customer Intention in Mobile Commerce Contexts. Second International Conference on MultiMedia and Information Technology, 310-3।3.

WU, J.H., and Wang, S.C. 2005. What drives mobile commerce?: An empirical evaluation of the revised technology acceptance model. Information \& Management, 42 (5), 719729.

YOON, C., and Kim, S. 2007. Convenience and TAM in a ubiquitous computing environment: The case of wireless LAN. Electronic Commerce Research and Applications, 6: 102-II2.

YOON, C. 2009. The effects of national culture values on consumer acceptance of e-commerce: Online shoppers in China. Information \& Management, 46, 294-30I.

YOON, C. 2010. Antecedents of customer satisfaction with online banking in China:The effects of experience. Computers in Human Behaviour, 26, I296-1304.

YOUSAFAZAI, S.Y., Foxall, G., and Pallister, J.G. 2010. Explaining Internet Banking Behaviour:Theory of Reasoned Action, Theory of Planned Behaviour, or Technology Acceptance Model? Journal of Applied Social Psychology, 40 (5), I I721202. 
YOUSAFAZAI, S., and Yani-de-Soriano M. 2012. Understanding customer-specific factors underpinning internet banking adoption. International Journal of Bank Marketing, 30 (I), 60-8I.

ZAK, P.J., and Knack, S. 20II. Trust and growth. Economic Journal, III, 295-32I. 